\title{
Techno-economic analysis of PEM fuel cells role in photovoltaic-based systems for the remote base stations
}

\author{
Dario Bezmalinovic ${ }^{a, b}$, Tolj Ivan ${ }^{\mathrm{b}}$, Frano Barbir ${ }^{\mathrm{b}}$ \\ ${ }^{a}$ Department of Thermodynamics, Thermotechnics and Heat Engines, Faculty of Electrical Engineering, \\ Mechanical Engineering and Naval Architecture, University of Split, Ruđera Boškovića 32, 21000 Split, \\ Croatia \\ ${ }^{\mathrm{b}}$ Institut de Robòtica i Informàtica Industrial, CSIC-UPC, Parc Tecnològic de Barcelona. C/ Llorens i \\ Artigas 4-6, 08028 Barcelona, Spain
}

\begin{abstract}
Expansion of telecommunication networks even to the most remote areas where connection to the utility grid could never be justified, especially in touristic regions, has led to the increasing need for stand-alone power systems. In Adriatic coastal area employment of hybrid photovoltaic-based systems is straightforward due to high sun potential. Inherent intermittent nature of renewable sources is especially not compatible with telecommunication system who require uninterrupted power supply. This leads to the need of not only energy storage, but also a "back up" solution in the case of primary system failure. Emphasis is put on the system reliability and simplicity while system price is not necessarily top priority. Usual approach of using diesel generators as a "back up" has been challenged by the introduction of PEM fuel cells. Even with hydrogen technologies market development still lagging behind some comparable advantages such as high energy conversion efficiency, silent operation and no emissions make PEM fuel cells a legitimate candidate for replacing traditional oil burning generators. Technoeconomic analysis of various stand-alone power systems for the remote base station on an Adriatic island is made. At the moment, levelized cost of electricity point of view still gives slight advantage to the diesel generators. Long term reliability of PEM fuel cells system still needs to be examined in practice, as this combined with pro-environmental characteristics of fuel cells can make the difference especially in pristine and protected areas. Furthermore, uncertain petroleum market and fast developing hydrogen technology market could reverse this trend in the near future.
\end{abstract}

Keywords: Stand-alone power system; remote telecommunications base station; photovoltaics; PEM fuel cells; levelized cost of electricity 


\section{Introduction}

Stand-alone power systems have been widely used for energy supply in remote areas. Systems comprising photovoltaic (PV) and/or wind generators combined with batteries are especially attractive today. Problems with these systems are their high prices which are still far from being competitive with grid electricity. Alternatively, conventional solution is to use diesel/gasoline generators but the price of electricity from diesel generators is also several times higher than the one from the grid. Price of the diesel fuel in most of the European countries is roughly about $0.2 \$$ per $\mathrm{kWh}$ [1]. With generator's and $\mathrm{AC} / \mathrm{DC}$ converter's efficiencies taken into account this rises to about $0.6 \$$ per $\mathrm{kWh}$ and these are just fuel operating costs excluding capital and maintenance costs. For comparison, grid electricity prices range from 0.12 to $0.34 \$ / \mathrm{kWh}$ in EU countries [1]. In Croatia, average price of the grid $\mathrm{kWh}$ is 0.17 \$ [2].

However, when designing stand-alone power system for the small remote consumers, like the mobile phone base stations, reliability and simplicity are far more important than the electricity price. On one hand, like all communication equipment, base stations require $100 \%$ system reliability $24 \mathrm{~h} /$ day, i.e. power system supply must never fail. On the other hand remote base stations have the advantage that, unlike those in densely inhabited areas, their power demand is more or less constant (with small seasonal variations) making it easier to design reliable stand-alone power system. Since just one power failure could cause immeasurable damage, use of "back up" power system is necessity in telecommunication. Straightforward solution would be the use of small diesel generator as a "back up" for, say, PV/battery power system in case of repeated poor weather conditions or unexpected system failure. Even though it seems at first glance that these requirements even more raise the cost of the already expensive installation, it will be shown that integrating "back up" in the power generation can not only downsize the whole system but can also make a significant savings in total costs. Generators do not necessarily have to be used only as a "back up" but can also actively participate in electricity generation during months of lower sun intensity. With this, oversizing of expensive PV arrays and bulky batteries due to lower sun irradiation during winter can be avoided.

Objective of this study is to analyze the possibilities of using PEM fuel cells instead of usual diesel generators as a "back up". The idea is quite intuitive, both devices are reliable and capable of quick response yet PEM fuel cells have some advantages which make them eligible candidate for replacing conventional generators:

- higher energy conversion efficiency

- quiet operation

- $\quad$ high flexibility (can operate very efficiently at low powers)

- simple and cheap maintenance (minimum moving parts, no lubrication)

- operates at lower temperatures (no danger of causing fire with hot exhaust)

- zero emissions

Internal combustion engines (ICE) have low efficiency which has its maximum at rated power. With decreasing the load, efficiency drops even further and the drop is 
tremendous at loads lower than $40 \%$ of the rated power. Together with the AC/DC converter losses accounted for, average efficiency of the typical diesel generator is about $20 \%$ [3].

On the other hand, PEM fuel cells have approximately $40 \%$ efficiency at rated power and contrary to ICE, their efficiency increases with lower loads, Fig. 1. So not only that the fuel cells are more efficient, they are also more flexible and can serve greater range of loads even down to only several percent of the rated power.

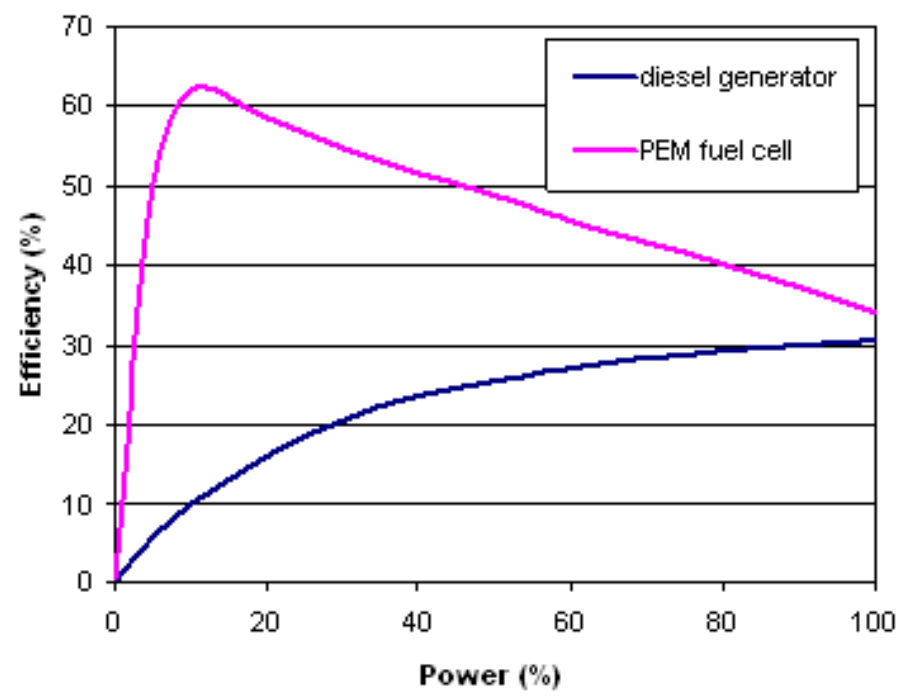

Fig. 1. Efficiencies of diesel generator and PEM fuel cells.

Furthermore, PEM fuel cells emit no greenhouse or any other gases except for water vapor, and reducing the emission of $\mathrm{CO}_{2}$ is especially welcomed nowadays. In comparison, $500 \mathrm{~W}$ diesel generator operating $8 \mathrm{~h} /$ day emits about one metric ton of $\mathrm{CO}_{2}$ over a year. Even though fuel cells direct emissions are zero, indirect emissions depend on hydrogen generation technology but even with the most "unclean" process (natural gas reforming) $\mathrm{CO}_{2}$ emissions can be $60 \%$ lower than with the fossil fuels burning in ICE [4, 5].

The main drawbacks of fuel cells in comparison with the diesel generators are still the unit cost and problems with hydrogen generation and storage. With mass production not in sight unit cost of the fuel cells is still high $(2000-6000 \$ / \mathrm{kW}$, depending on the size with smaller units typically more expensive $[6,7]$. Some projections say that the unit cost of the fuel cells should equal those of ICE once mass production is achieved $[8,9]$.

In most European countries, hydrogen market has not developed in a way that the hydrogen price would be competitive with the fossil fuels. In United States it is possible to buy compressed hydrogen at some fuel stations with the price of about $5 \$ / \mathrm{kg}(\sim 0.13$ $\$ / \mathrm{kWh})[10,11]$ and Department of Energy projections say that in the near future price could go down to $3 \$ / \mathrm{kg}[12,13]$. Besides, uncertainty in the oil market, where the long term oil prices can only go up, could make the difference.

Hydrogen storage problems are well known because they are related to the hydrogen's low volumetric density (gas with density $0.09 \mathrm{~kg} / \mathrm{m}^{3}$ ). The most common storage method 
is using high pressure cylinders (200-700 bar). Still, $1 \mathrm{~kg}$ of hydrogen compressed at 200 bar takes 65 liters and that is just gas without tank volume. This is far better than the lead acid batteries (volumetrically and gravimetrically) but incomparable to diesel fuel. In Table 1 comparison between different types of energy storage is shown for the total and useful energy stored with conversion efficiencies (to DC electricity) of $0.35,0.9$ and 0.2 accounted for hydrogen, battery and diesel fuel respectively.

Table 1. Energy density.

\begin{tabular}{|lcccc|}
\hline \multirow{2}{*}{ energy storage } & \multicolumn{2}{c}{ total energy } & \multicolumn{2}{c|}{ useful energy } \\
& $\mathbf{k W h} / \mathbf{k g}$ & $\mathbf{k W h / l}$ & $\mathbf{k W h} / \mathbf{k g}$ & $\mathbf{k W h / l}$ \\
\hline compressed hydrogen (200 bar) & 2 & 0.55 & 0.7 & 0.1925 \\
lead-acid battery & 0.04 & 0.1 & 0.036 & 0.09 \\
diesel fuel & 12 & 10 & 2.4 & 2 \\
\hline
\end{tabular}

While for mobile applications energy densities play a major role and therefore it is very difficult to compete with fossil fuels, for stationary applications this is not the biggest issue. And hydrogen as a storage has one clear advantage over batteries (apart from energy density) and that is life span. Batteries have limited number of charge/discharge cycles which progressively decreases with depth of discharge. In reality this means frequent replacement. Also, actual stored energy in batteries strongly depend on discharge current and in real world applications this can be less than $50 \%$ of the rated capacity.

\section{Load and resource analysis}

\subsection{Mobile phone base stations}

In this paper techno-economical analysis of several PV-based stand-alone power systems for remote areas has been made. As an example, typical mobile phone base station from a Croatian mobile operator positioned at the island of Brač was taken in the analysis. Remote base station is typically small consumer with nearly constant power consumption. According to the data from the operator one specific type of such a base station analyzed here has an average power consumption of $400 \mathrm{~W}$ throughout the year with the exception of summer months when average consumption goes up to $500 \mathrm{~W}$ due to rise in local population caused by tourism.

\subsection{Solar resources}

Island of Brač is located in south Croatia at the latitude $43^{\circ} 19^{\prime}$ N. It has about 2600 sunny hours a year and average annual insolation of about $5800 \mathrm{MJ} / \mathrm{m}^{2}$. Insolation is measure of solar radiation energy received on a given surface area at a given time. Figure 2 shows annual distribution of the mean daily insolation on the inclined plane for the different slopes for the island of Brač calculated by Liu, Jordan and Klein formula [14, 15]:

$H_{\beta}=H\left[\left(1-H_{\mathrm{d}} / H\right) R_{\mathrm{b}}+H_{\mathrm{d}} / H(1+\cos \beta) / 2+\rho(1-\cos \beta) / 2\right]$ 
Where:

$\mathrm{H}_{\beta}$ - mean daily insolation on the inclined plane $\left(\mathrm{MJ} / \mathrm{m}^{2}\right)$,

$H$ - mean daily total insolation on the horizontal plane $\left(\mathrm{MJ} / \mathrm{m}^{2}\right)$,

$H_{\mathrm{d}^{-}}$mean diffuse daily insolation on the horizontal plane $\left(\mathrm{MJ} / \mathrm{m}^{2}\right)$,

$R_{\mathrm{b}}$ - ratio of mean daily direct insolation on the inclined and horizontal plane,

$\beta$ - slope to the south $\left(^{\circ}\right)$

$\rho$ - ground reflectance; albedo.

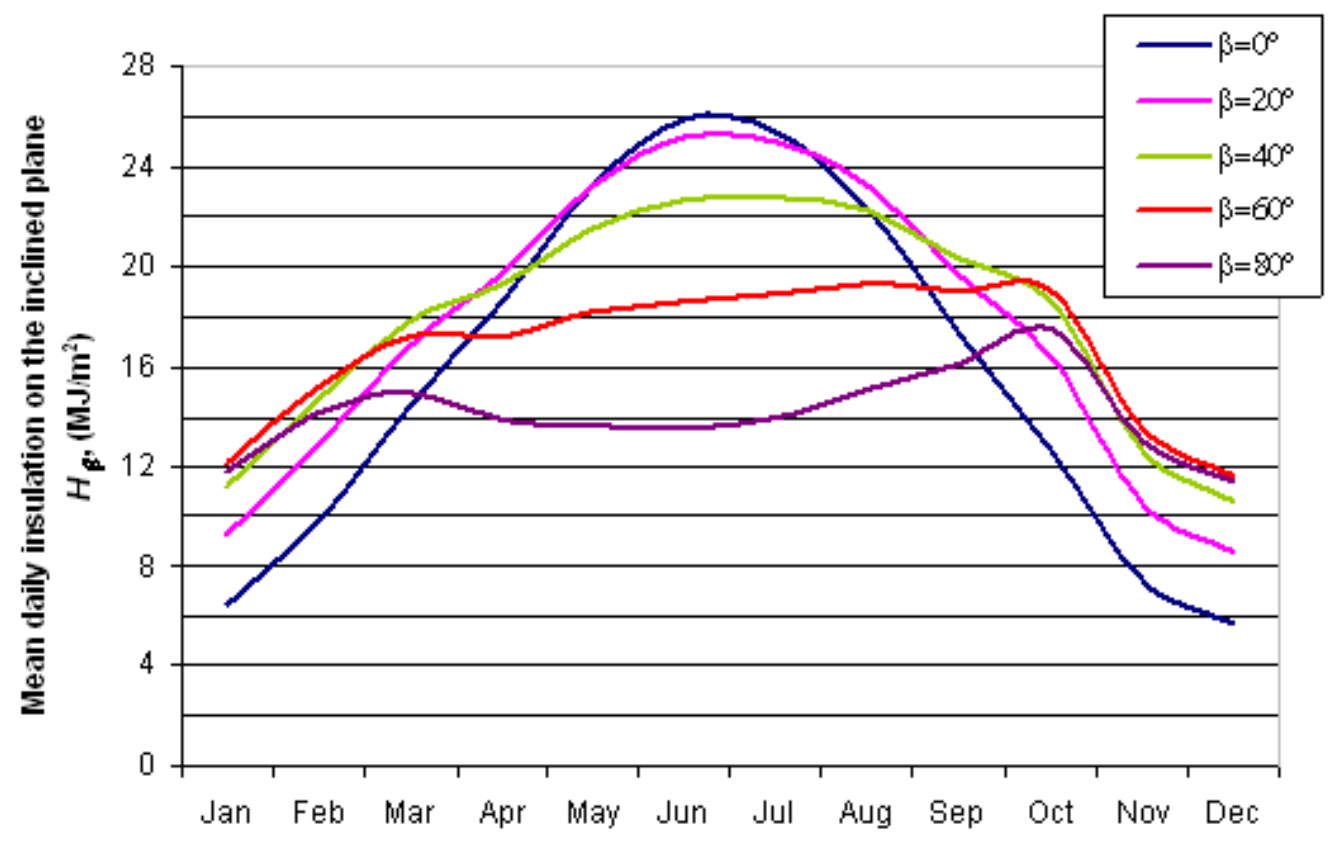

Fig. 2. Annual distribution of the mean daily insolation on the island of Brač for the different slopes, $\beta$.

Optimum panel slope depends on the type of the system. For grid-tied systems or systems with "back up" optimal slopes are generally those with highest annual insolation i.e. highest annual electricity generation. However, for systems with no "back up" optimal slope is the one with highest mean daily insolation value of the weakest month in a year (typically December). In Fig. 3 the total annual insolation with respect to the panel slope is shown. As it can be seen, maximum annual insolation of $6541 \mathrm{MJ} / \mathrm{m}^{2}$ is reached for the slope of $35^{\circ}$. On the other hand, slope of $65^{\circ}$ has only $5888 \mathrm{MJ} / \mathrm{m}^{2}$ annual insolation but its weakest month in a year (December) has the highest mean daily average insolation of $11.77 \mathrm{MJ} / \mathrm{m}^{2}$, compared to $10.24 \mathrm{MJ} / \mathrm{m}^{2}$ for the $35^{\circ}$ slope (also December). For systems with no "back up" choosing $65^{\circ}$ slope means $13 \%$ less PV power installed compared to $35^{\circ}$ slope, while for grid-tied system choosing $35^{\circ}$ slope means saving $11 \%$ on grid electricity annually compared to $65^{\circ}$ slope. 


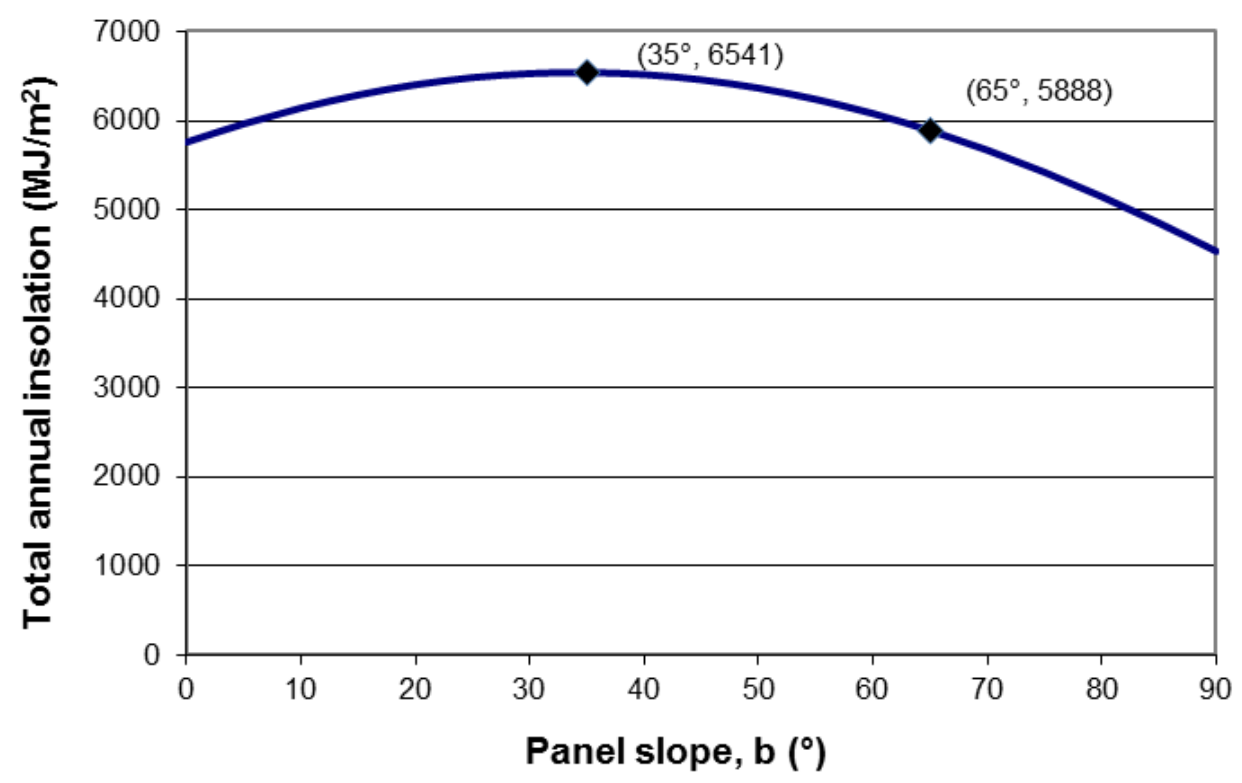

Fig. 3. Total annual insolation in dependence on the panel slope.

\section{Economic analysis}

Net amount of total investment required for stand-alone power system through projected lifetime shown in a present value is called net present cost. Net present cost is the difference between present values of system cost and system salvage:

$N C_{\mathrm{P}}=S C_{\mathrm{P}}-S S_{\mathrm{P}}$

Where:

$N C_{\mathrm{P}} \quad$ - net present cost (\$),

$S C_{\mathrm{P}} \quad$ - present system cost $(\$)$,

$S S_{\mathrm{P}} \quad$ - present system salvage (\$).

Present system cost includes initial capital cost $(I C C)$ and present operating cost $\left(O C_{\mathrm{P}}\right)$ :

$S C_{\mathrm{P}}=I C C+O C_{\mathrm{P}}$

Initial capital cost is total cost of all the installed components at the beginning of the projected lifetime. Present operating cost includes present cost of all the replaced components during project lifetime and all the operating expenses like maintenance and fuel costs.

Present system salvage is present value of all system's components value after the projected lifetime. At the end of the system's projected lifetime some components may still have some worth (which can be considerable) and this should be deducted from the system's cost calculation for the projected period. System salvage (SS) is calculated as the sum of each component's price $\left(C P_{\mathrm{i}}\right)$ multiplied by ratio of remaining $\left(R T_{\mathrm{i}}\right)$ and projected $\left(P T_{i}\right)$ life-cycle of the each component: 
$S S=\sum_{\mathrm{i}}\left(C P_{\mathrm{i}} \cdot R T_{\mathrm{i}} / P T_{\mathrm{i}}\right)$

All present costs are calculated with given annual interest rate.

It is only the final cost of kWh that gives a clear picture of how successful the system really is. Levelized cost of electricity is the average cost of useful $\mathrm{kWh}$ generated by the system. It is expressed as total annualized system cost divided by the electricity consumed by the load annually:

$L C E=S C_{\mathrm{A}} / U E_{\mathrm{A}}$

Where:

$L C E \quad$ - levelized cost of electricity $(\$ / \mathrm{kWh})$,

$S C_{\mathrm{A}}$ - annualized system cost $(\$ / \mathrm{y})$,

$U E_{\mathrm{A}} \quad$ - annual useful electricity; electricity consumed by the load in 1 year $(\mathrm{kWh} / \mathrm{y})$.

Annualized system cost is net present cost spread over system's projected lifetime with annual installments:

$S C_{\mathrm{A}}=N C_{\mathrm{P}} \cdot C R F$

$C R F$ is capital recovery factor which depends on the project lifetime and annual interest rate:

$C R F=\frac{i \cdot(i+1)^{n}}{(i+1)^{n}-1}$

Where:

i - annual interest rate (\%),

$n \quad$ - project lifetime (years).

Real annual interest rate depends on inflation. However, assuming that inflation affects all components' prices equally, annual interest rate can be taken as constant for the sake of comparison of different system solutions.

\section{Results and discussion}

Three different stand-alone power systems were optimized and compared. Only constraint was $100 \%$ reliability, and levelized cost of electricity $(L C E)$ is the only criteria for optimization.

Analyzed systems are:

- PV / battery,

- PV/ battery / diesel generator,

- PV / battery / PEM fuel cells. 
Optimization analysis was done with the help of simulation program HOMER [16] which is free software developed by the National Renewable Energy Laboratory (NREL). It searches for the cheapest solution of the proposed system configuration according to input data about load, resources and component characteristics (both technical and economical). For simplicity, load input is set to be constant $400 \mathrm{~W}$ for the whole year except for June, July and August where it is set to be constant $500 \mathrm{~W}$ due to the aforementioned reasons.

For the PV, price of $4000 \$ / \mathrm{kWp}[17,18]$ with lifetime of 20 years and derating factor of $90 \%$ were taken as inputs.

For the batteries, 300 Ah deep cycle lead-acid batteries (12 V) with $600 \$$ unit cost were chosen. They have about 2000 cycles to failure at 50\% depth of discharge but are replaced anyhow after 10 years if still operational. Economic analysis was made for the project lifetime of 20 years with the fixed annual interest rate of $6 \%$. All the load, resource, technical and economic input data can be seen in the Table A.1 in the Appendix.

\section{1. $P V /$ battery}

The first analyzed case is basic and the simplest one. The idea is to utilize sun energy via PV modules and the excess produced energy during periods of high sun intensity store in the batteries, Fig. 4.

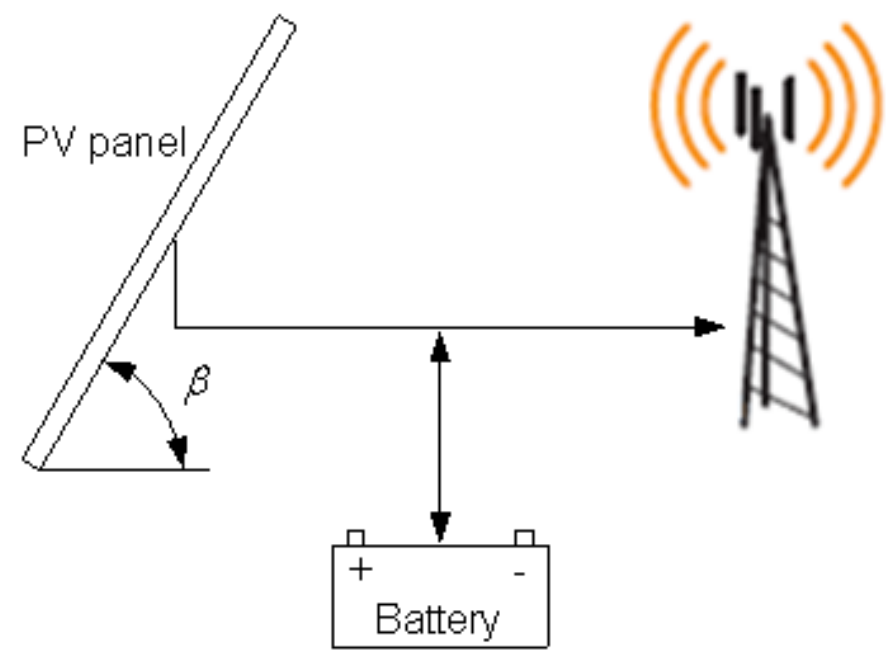

Fig. 4. System configuration without "back up".

In the Table 2 levelized costs of electricity and optimum configurations for different panel slopes are shown. As expected, the cheapest system is the one with highly inclined panel $\left(55^{\circ}<\beta<65^{\circ}\right)$. System consist of $3.5 \mathrm{kWp}$ PV modules and 18 batteries and $L C E$ is $0.722 \$ / \mathrm{kWh}$. Initial capital cost is the price of the initially installed PV panels and batteries while operating costs are related to the fact that during the project lifetime battery pack must be replaced once. 
Table 2. Levelized cost of electricity of the optimum PV/battery systems for the different panel slopes.

\begin{tabular}{|lccccccc|}
\hline panel slope, $\boldsymbol{\beta} \mathbf{(}^{\circ}$ ) & 35 & 40 & 45 & 50 & 55 & 60 & 65 \\
\hline PV (kWp) & 4.2 & 4.2 & 4 & 4 & 3,5 & 3.5 & 3.5 \\
battery; 12V/300Ah (unit) & 16 & 16 & 16 & 16 & 18 & 18 & 18 \\
initial capital cost (\$) & 26400 & 26400 & 25600 & 25600 & 24800 & 24800 & 24800 \\
operating cost (\$/y) & 467 & 467 & 467 & 467 & 526 & 526 & 526 \\
\hline levelized cost (\$/kWh) & 0.744 & 0.744 & 0.726 & 0.725 & 0.723 & 0.722 & 0.722 \\
\hline
\end{tabular}

Figure 5 shows comparison of systems with $35^{\circ}$ and $65^{\circ}$ panel slopes. Due to extra PV installed to compensate low winter production system with $35^{\circ}$ slope generates $41.7 \%$ excess power. In the better balanced $65^{\circ}$ system excess is $23.6 \%$.

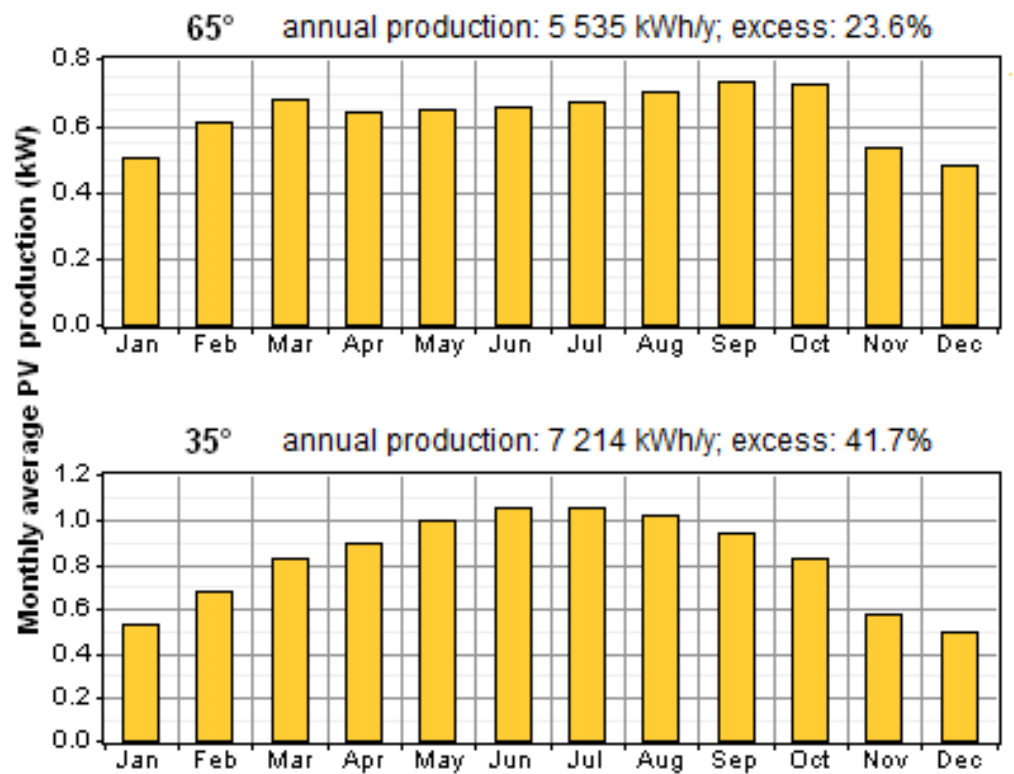

Fig. 5. Monthly average PV electricity production for the systems with $35^{\circ}$ and $65^{\circ}$ slopes.

\section{2. $P V /$ battery / diesel generator}

Incorporation of "back up" in telecommunication systems is not only mandatory but also desirable. Experience has shown that the PV / battery / generator systems are very reliable sources of electricity [19]. PV modules and diesel generators have some complement characteristics:

- PV capital costs are high, generator's are low

- generators operating costs are high, PV's are negligible

- electricity from generator is available all the time while PV's is intermittent

The addition of a diesel generator increases reliability of the system but if it is used as an integral part of the system, and not only as "back up", also decreases need for the 
installed PV power and batteries which finally lowers system cost. Scheme of the system with AC/DC converter is shown in Fig. 6.

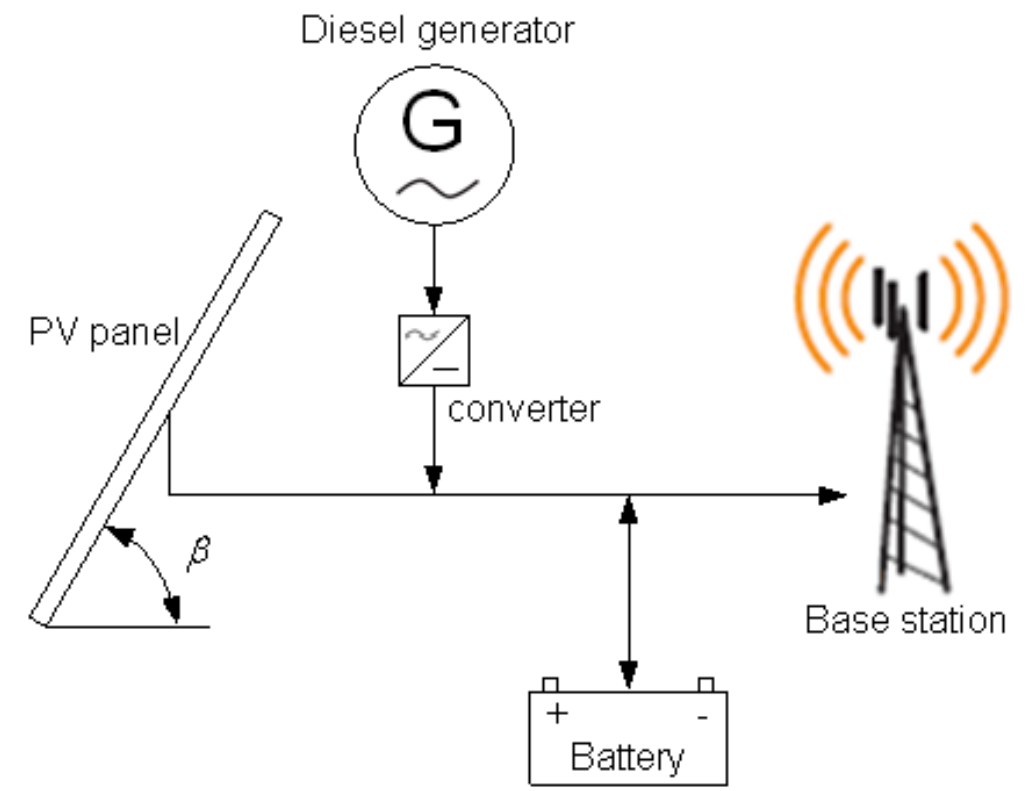

Fig. 6. System configuration with diesel generator "back up".

Analysis was conducted for the two different scenarios:

a) fuel price of $1.8 \$$ per liter according to the current situation in Croatia,

b) fuel price of $2.5 \$$ per liter according to the expected global rise of fossil fuels.

Results of both scenarios are given in Table 3. As expected, introduction of the integral "back up" leads to significant reduction of the system cost. It is shown that the optimum results are obtained for lower panel slopes $\left(35^{\circ}\right)$ which is in accordance with other authors [3]. Panel slopes are set for maximizing PV's annual output while winter shortcomings are met by generator's increased engagement, Fig. 7.

Results also indicate that pessimistic scenario of $2.5 \$$ per liter of fuel does not influence final price of the $\mathrm{kWh}$ that much. Reason for this is that annual fuel consumption for the $35^{\circ}$ slope and scenario a) is only 167 liters and generators production ratio is around $10 \%$. Excess electricity is $12.2 \%$ in scenario a) and $14.7 \%$ in scenario b). Annual $\mathrm{CO} 2$ emissions are $439 \mathrm{~kg} / \mathrm{y}$ and $405 \mathrm{~kg} / \mathrm{y}$ for the scenarios a) and b) respectively. 
Table 3. Levelized cost of electricity of the optimum systems with generator "back up" for different panel slopes and different fuel price scenarios.

\begin{tabular}{|lccccccc|}
\hline panel slope, $\boldsymbol{\beta}\left(\mathbf{(}^{\circ}\right.$ & 35 & 40 & 45 & 50 & 55 & 60 & 65 \\
\hline a) fuel price 1.8 \$ /I & & & & & & & \\
\hline PV (kWp) & 2.5 & 2.6 & 2.6 & 2.6 & 2.6 & 2.6 & 2.7 \\
battery; 12V/300Ah (unit) & 8 & 8 & 8 & 8 & 8 & 8 & 8 \\
generator (kW) & 0.6 & 0.6 & 0.6 & 0.6 & 0.6 & 0.6 & 0.6 \\
converter (kW) & 0.6 & 0.6 & 0.6 & 0.6 & 0.6 & 0.6 & 0.6 \\
initial capital cost (\$) & 16000 & 16400 & 16400 & 16400 & 16400 & 16400 & 16800 \\
operating cost (\$/y) & 606 & 579 & 587 & 600 & 619 & 654 & 655 \\
\hline levelized cost (\$/kWh) & 0.534 & 0.535 & 0.538 & 0.542 & 0.547 & 0.557 & 0.566 \\
\hline b) fuel price 2.5 \$ /I & & & & & & & \\
\hline PV (kWp) & 2.5 & 2.6 & 2.6 & 2.7 & 2.8 & 2.9 & 2.9 \\
battery; 12V/300Ah (unit) & 8 & 8 & 8 & 8 & 8 & 8 & 8 \\
generator (kW) & 0.6 & 0.6 & 0.6 & 0.7 & 0.6 & 0.6 & 0.6 \\
converter (kW) & 0.6 & 0.6 & 0.6 & 0.7 & 0.6 & 0.6 & 0.6 \\
initial capital cost (\$) & 16000 & 16400 & 16400 & 17000 & 17200 & 17600 & 17600 \\
operating cost (\$/y) & 723 & 686 & 697 & 648 & 665 & 657 & 701 \\
\hline levelized cost (\$/kWh) & 0.565 & 0.564 & 0.568 & 0.571 & 0.577 & 0.585 & 0.597 \\
\hline
\end{tabular}

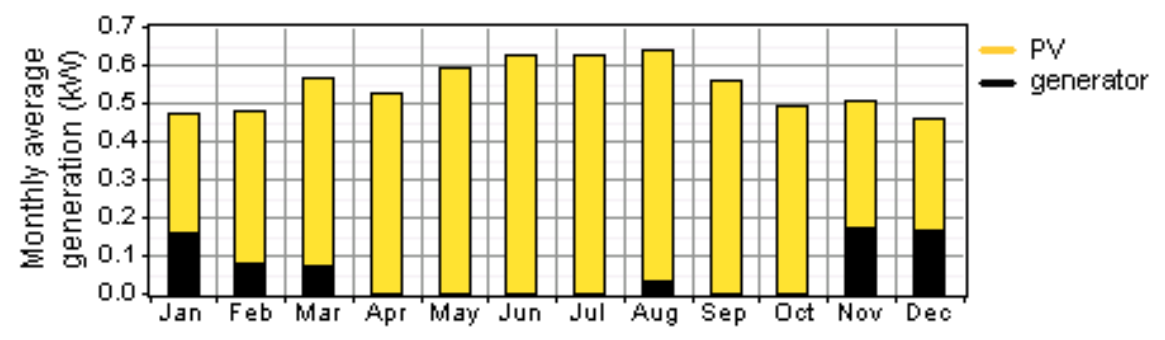

Fig. 7. Generator's and PV's monthly average electricity production.

\subsection{PV / battery / PEM fuel cells}

Use of fuel cells as an alternative to the diesel generators in the times of uncertain fuel prices and emphasizing on ecological issues, especially $\mathrm{CO}_{2}$ emissions, becomes appealing. Fuel cells as an electricity generator have some similarities with diesel generators but also some differences. It is a proven and reliable source of electricity whose life-cycle is comparable with those of diesel generators. But, due to still undeveloped market of hydrogen and fuel cell technologies, unit cost of the fuel cells, as well as hydrogen price, is still relatively high compared to "fossil" competition. However, higher efficiencies, higher flexibility, cheaper maintenance and clean exhaust give them reasonable advantage over ICE from the technical and environmental point of view.

Major problem in the every analysis involving some kind of hydrogen technology is obtaining real market values. Most of the PEM fuel cells being produced today are still not commercialized in a way that the prices are well defined. There is still no series production and therefore units are being sold by individual agreements. Unit prices are 
quite high, especially for low power units $(\sim 1 \mathrm{~kW})$ they go up to $6000 \$ / \mathrm{kW}$. Some sources cite $2000 \$ / \mathrm{kW}$ units with optimistic prognosis of $500 \$ / \mathrm{kW}$ in the near future $[6$, $8,9]$.

For the sake of the analysis three different scenarios were taken in calculation: 1) 2000 $\$ / \mathrm{kW}, 2) 4000 \$ / \mathrm{kW}$ and 3) $6000 \$ / \mathrm{kW}$.

Same problem is with the hydrogen market. While in USA and some EU countries it is possible to buy highly compressed hydrogen at reasonable price in Croatia and most other countries hydrogen is very expensive due to low demand ( $85 \$ / \mathrm{kg}$ in Croatia).

Similarly to fuel cells, three different scenarios are analyzed: a) $5 \$ / \mathrm{kg}$, b) $10 \$ / \mathrm{kg}$ and c) $20 \$ / \mathrm{kg}$.

Scheme of this system is the similar to previous case, only the diesel generator was replaced by the PEM fuel cells and there is no need for a converter since fuel cells generate DC current, Fig 8.

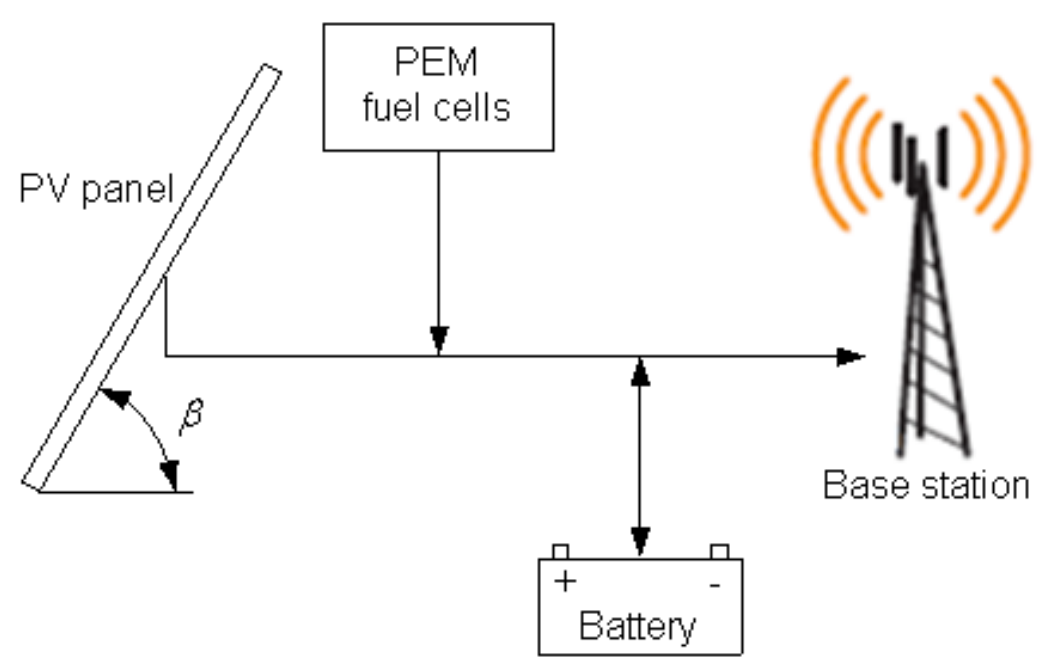

Fig. 8. System configuration with fuel cells as a "back up".

Figure 9 shows dependence of levelized cost of electricity on different panel slopes and different scenarios of hydrogen and fuel cell prices. One can realize that the hydrogen price plays bigger role on system cost than the fuel cells' price. This is because initial capital cost of the $500 \mathrm{~W}$ fuel cells influences final system cost much less than operating cost in which hydrogen fuel expenses are dominant. In the most optimistic 1-a scenario, hydrogen consumption is $56 \mathrm{~kg} / \mathrm{y}$ which means that in less than 5 years hydrogen consumption outprices fuel cells' capital costs. 


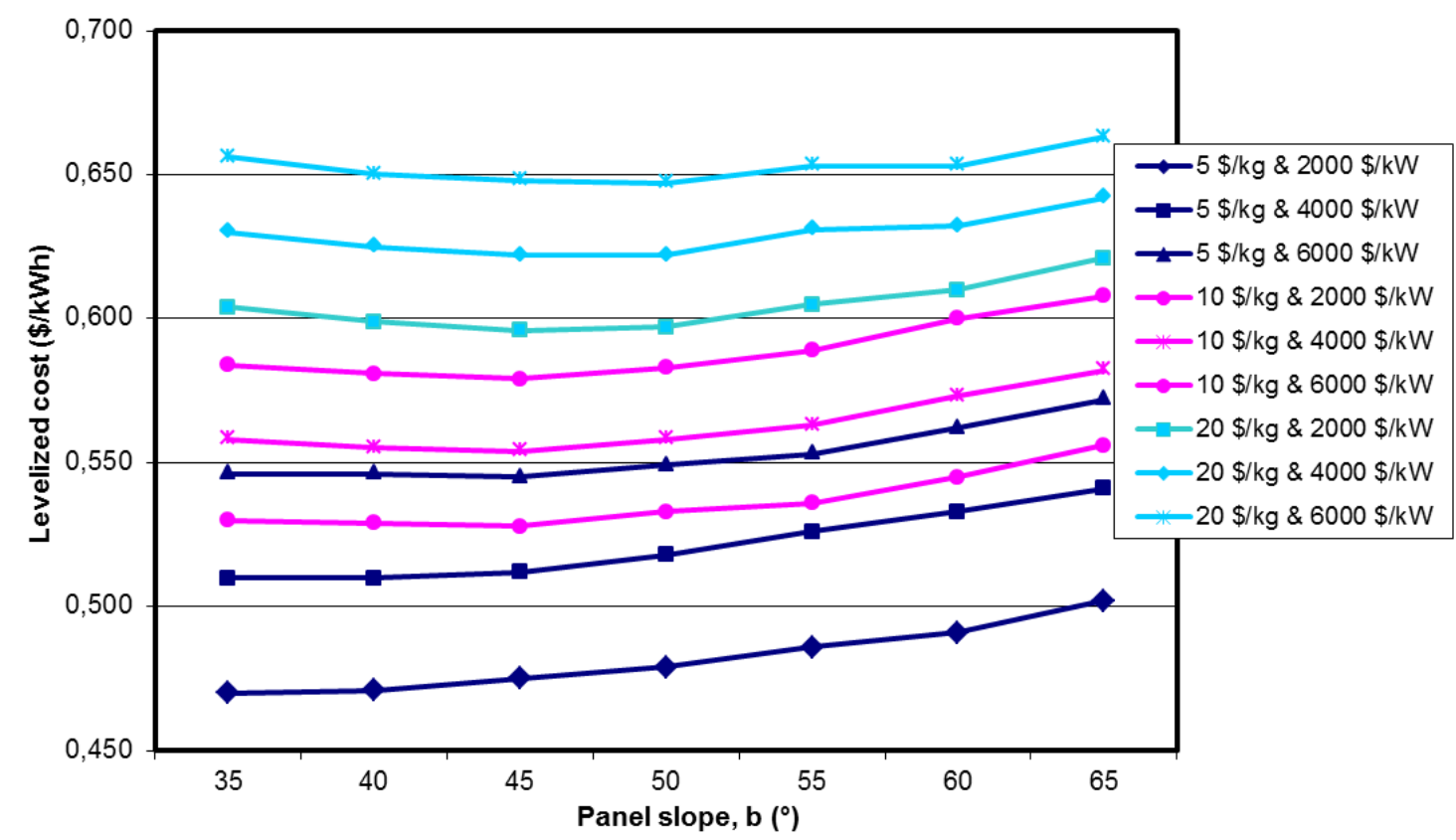

Fig. 9. Dependence of levelized cost of electricity on different panel slopes and different scenarios of hydrogen and fuel cells' prices for the optimum systems.

Results show that with $5 \$ / \mathrm{kg}$ for hydrogen even the $4000 \$ / \mathrm{kW}$ for fuel cells gives lower LCE than the current fuel price scenario with diesel generator $(0.510 \$ / \mathrm{kWh}$ vs. 0.534 $\$ / \mathrm{kWh}$ ) while for $6000 \$ / \mathrm{kW}$ LCE price is only slightly higher, $0.545 \$ / \mathrm{kWh}$ ). At 10 $\$ / \mathrm{kg}$ price for hydrogen and $2000 \$ / \mathrm{kW}$ for fuel cells LCE $(0.528 \$ / \mathrm{kWh})$ is still lower than for the system with diesel generator while for the $4000 \$ / \mathrm{kW}$ fuel cell price is a bit higher $(0.554 \$ / \mathrm{kWh})$.

However, one should notice that calculations of both systems, with diesel generator and with PEM fuel cells as "back up", do not include fuel storage expenses. And while the oil tank is cheap ( $\sim 500 \$$ for the 300 liter tank), compressed hydrogen tank is two orders of magnitude more expensive. 50 liter $/ 200$ bar tank can contain $0.8 \mathrm{~kg}$ of hydrogen and its price is about $500 \$$ a piece. This means that for the most optimistic 1-a scenario it would take 70 of those tanks for one annual refuel which is additional $30000 \$$ of system cost. This increases final $\mathrm{kWh}$ price more than twice. There are several ways to deal with this problem:

1) increasing hydrogen storage pressure (say 700 bar),

2) more refuelings (say twice or three times a year),

3) limiting annual hydrogen consumption,

4) "on-site" hydrogen generation via water electrolysis with PV's excess electricity.

Increasing tank pressure to 700 bar maybe decreases the need for storage volume by two thirds but it does not help much economically, since those tanks are very expensive, and the equipment such as valves, pressure regulators, pipes, etc., should also be adapted to high pressure system.

More refuelings a year (during regular maintenance checks) also decreases the need for storage tanks, but still the capital cost is high. 
However, limiting annual hydrogen consumption combined with more refuelings a year could be the solution. Limiting annual hydrogen consumption to $15 \mathrm{~kg} / \mathrm{y}$ together with 2 refuelings a year results in the need for 10 storage tanks (50 liter/200 bar) while limiting hydrogen consumption further to $9 \mathrm{~kg} / \mathrm{y}$ results in the need for only 6 tanks with 2 refuelings. Results show that fuel cells' price has no effect on the choice between abovementioned systems and has overall much smaller effect on LCE than hydrogen price. For the fuel cells' price of $2000 \$ / \mathrm{kW}$ limiting annual hydrogen consumption to 15 $\mathrm{kg} / \mathrm{y}$ is better in the case of cheap hydrogen scenario $(5 \$ / \mathrm{kg})$ while in the case of expensive hydrogen scenario $(20 \$ / \mathrm{kg})$ system with $9 \mathrm{~kg} / \mathrm{y}$ limitation is better, Table 4 (storage cost included).

Table 4. Influence of the limited annual hydrogen consumption on the system. configuration and levelized cost of electricity for different hydrogen prices.

\begin{tabular}{|c|ccccccc|}
\cline { 2 - 8 } & $\begin{array}{c}\text { annual } \\
\text { consumption } \\
\text { (kg/y) }\end{array}$ & $\begin{array}{c}\text { PV } \\
\text { (kWp) }\end{array}$ & $\begin{array}{c}\text { battery } \\
\text { (unit) }\end{array}$ & $\begin{array}{c}\text { FC } \\
\text { (kW) }\end{array}$ & $\begin{array}{c}\text { storage } \\
\mathbf{5 0 L ;} \mathbf{2 0 0} \\
\text { bar } \\
\text { (unit) }\end{array}$ & $\begin{array}{c}\text { panel } \\
\text { slope } \\
\left.\mathbf{(}^{\circ}\right)\end{array}$ & $\begin{array}{c}\text { levelized } \\
\text { cost } \\
\text { (\$/kWh) }\end{array}$ \\
\hline $\mathbf{H 2}$ & 15 & 3 & 10 & 0.5 & 10 & 55 & 0.662 \\
$\mathbf{5} \mathbf{\$} / \mathbf{k g}$ & 9 & 3.3 & 12 & 0.5 & 6 & 55 & 0.675 \\
\hline $\mathbf{H 2}$ & 15 & 3 & 10 & 0.5 & 10 & 55 & 0.722 \\
$\mathbf{2 0} \mathbf{\$} / \mathbf{k g}$ & 9 & 3.3 & 12 & 0.5 & 6 & 55 & 0.711 \\
\hline
\end{tabular}

Figure 10 shows comparison of PV's and fuel cells' engagement throughout the year for the system with hydrogen consumption of $15 \mathrm{~kg} / \mathrm{y}$ at the price of $5 \$ / \mathrm{kg}$. Fuel cells' annual engagement is 503 hours with $4 \%$ of total electricity production ratio.

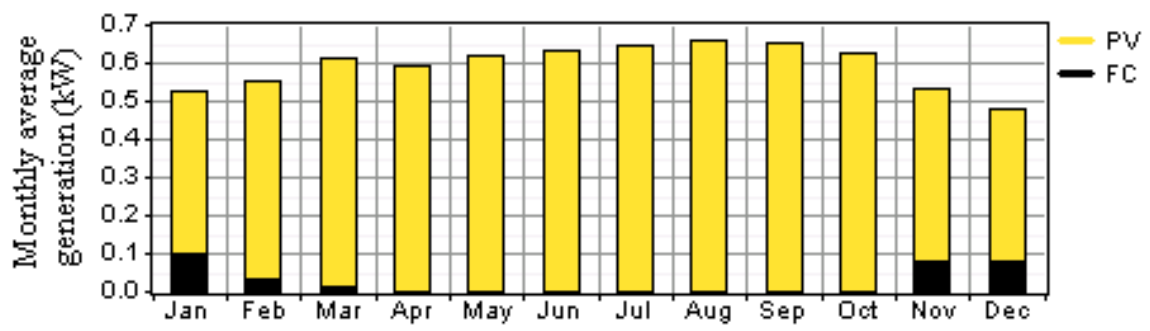

Fig. 10. Fuel cells' and PV's monthly average electricity production for the limited annual hydrogen consumption system $(15 \mathrm{~kg} / \mathrm{y})$.

All above calculations are conducted for the hypothetical hydrogen prices. For the current hydrogen price in Croatia fuel cells could never compete with diesel generators. Only solution in that case would be "on-site" generation of hydrogen via water electrolysis with excess electricity from PV, Fig. 11. 


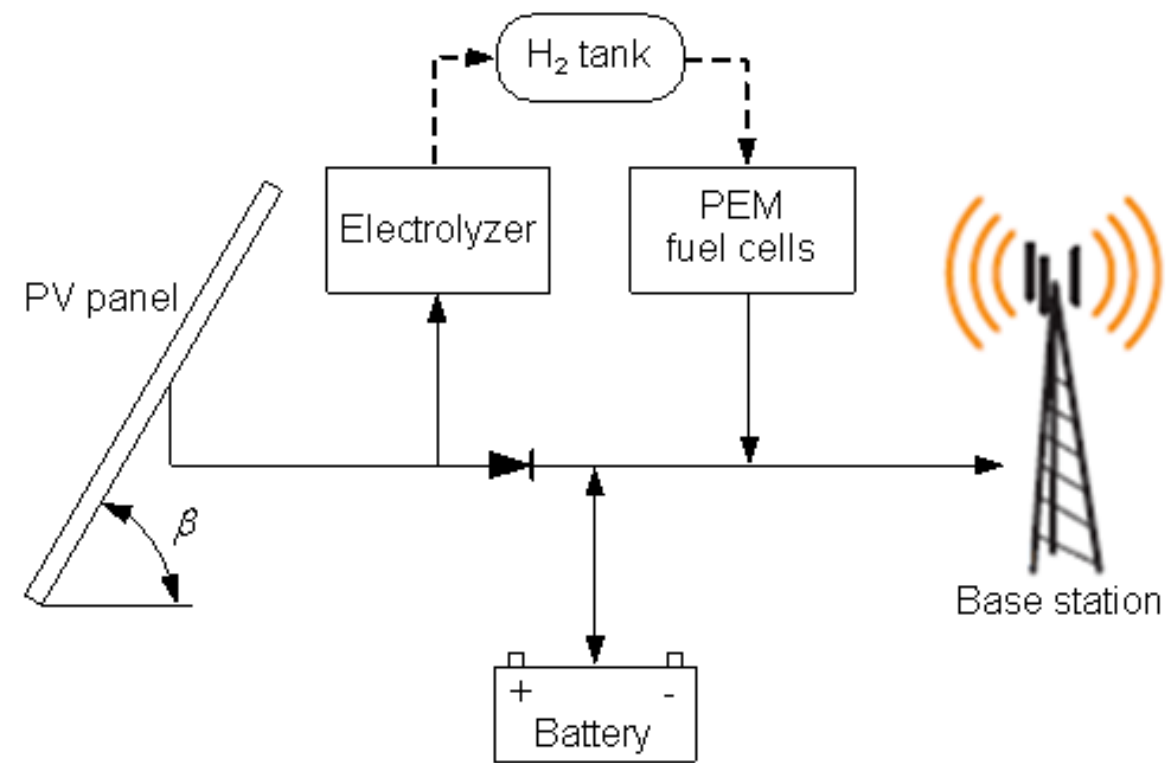

Fig. 11. "On-site" hydrogen generation via water electrolysis from PV's excess electricity.

With an "on-site" hydrogen generation system becomes totally autonomous and does not need any refueling. But with high current electrolyzer unit cost of $5000 \$ / \mathrm{kW}$ [13] LCE rises to $0.828 \$ / \mathrm{kWh}$ while for the optimistic electrolyzer cost projection [6] of 1500 $\$ / \mathrm{kW}$ LCE is $0.7 \$ / \mathrm{kWh}$ with exactly the same system configurations, Table 5. Fuel cells' total electricity production ratio is $3 \%$ in both cases.

Table 5. Levelized cost of electricity of the of the optimum systems with "on-site" hydrogen generation for different panel slopes and different electrolyzer costs.

\begin{tabular}{|cccccccc|}
\hline $\begin{array}{c}\text { electrolyzer } \\
\text { cost (\$/kW) }\end{array}$ & $\begin{array}{c}\text { PV } \\
(\mathbf{k W p})\end{array}$ & $\begin{array}{c}\text { battery } \\
\text { (unit) }\end{array}$ & $\begin{array}{c}\mathrm{EL} \\
\mathbf{( k W )}\end{array}$ & $\begin{array}{c}\mathrm{FC} \\
\mathbf{( k W )}\end{array}$ & $\begin{array}{c}\text { storage } \\
\mathbf{5 0 L} \text {; 200 bar } \\
\text { (unit) }\end{array}$ & $\begin{array}{c}\text { panel } \\
\text { slope } \\
\left(\mathbf{\circ}^{\circ}\right.\end{array}$ & $\begin{array}{c}\text { levelized } \\
\text { cost } \\
(\mathbf{\$} / \mathbf{k W h})\end{array}$ \\
\hline 5000 & 4 & 8 & 1.5 & 0.5 & 4 & 60 & 0.828 \\
1500 & 4 & 8 & 1.5 & 0.5 & 4 & 60 & 0.7 \\
\hline
\end{tabular}

It is clear that currently high electrolyzer price combined with extra PV power needed for system's sustainability ruins the system's economy Also, it should be mentioned that the final price would in reality be slightly higher due to the need for small hydrogen compressor not included in this analysis.

\section{Conclusion}

Even though use of hydrogen technologies in stand-alone power systems is very appealing, problems with hydrogen storage and its high price still present an obstacle in real world applications. Even with $2.5 \$$ per liter price of fossil fuels levelized cost of electricity for the system with diesel generator is still about $15 \%$ cheaper than levelized 
cost of the system with fuel cells with the most optimistic prices. Though significant, this difference in price is not necessarily crucial. For the telecommunications systems, reliability has priority over supposed price because just one failure could cause immeasurable damage to the company's image. ICE's reliability with all the drawbacks is more or less known, while long term reliability of PEM fuel cells is still to be examined in real world applications as this could be decisive.

\section{Appendix}

Table A.1. Input data

\begin{tabular}{|c|c|c|c|c|c|c|c|c|c|c|c|c|c|}
\hline \multicolumn{14}{|c|}{ Solar resource } \\
\hline \multicolumn{2}{|c|}{ Month } & Jan & Feb & Mar & Apr & May & Jun & Jul & Aug & Sep & Oct & Nov & Dec \\
\hline \multicolumn{2}{|c|}{$\begin{array}{l}\text { Daily average monthly } \\
\text { insolation }\left(\mathrm{kWh} / \mathrm{m}^{2} / \mathrm{d}\right)\end{array}$} & 1.8 & 2.72 & 3.98 & 5.17 & 6.46 & 7.2 & 7.06 & 6.21 & 4.82 & 3.52 & 2.07 & 1.59 \\
\hline \multicolumn{5}{|c|}{ PV } & \multicolumn{9}{|c|}{ Battery } \\
\hline Price & Lifetime & \multicolumn{3}{|c|}{ Derating factor } & \multicolumn{2}{|l|}{ Type } & \multicolumn{2}{|c|}{ Capacity } & \multicolumn{3}{|c|}{ Cycles to failure } & \multicolumn{2}{|c|}{ Price } \\
\hline $4000 \$ / \mathrm{kW}$ & 20 years & \multicolumn{2}{|c|}{$90 \%$} & \multicolumn{3}{|c|}{$12 \mathrm{~V}$ lead acid } & \multicolumn{2}{|c|}{$300 \mathrm{Ah}$} & \multicolumn{3}{|c|}{$\begin{array}{c}2100 \text { at } 50 \% \\
\text { depth of discharge }\end{array}$} & \multicolumn{2}{|c|}{600 \$/unit } \\
\hline \multicolumn{7}{|c|}{ Diesel generator } & \multicolumn{7}{|c|}{ AC/DC converter } \\
\hline Price & Lifetime & \multicolumn{3}{|c|}{ Maintenance cost } & \multicolumn{2}{|c|}{$\begin{array}{l}\text { Minimum } \\
\text { load ratio }\end{array}$} & \multicolumn{2}{|c|}{ Price } & \multicolumn{3}{|c|}{ Lifetime } & \multicolumn{2}{|c|}{ Efficiency } \\
\hline $1000 \$ / \mathrm{kW}$ & $15000 \mathrm{~h}$ & \multicolumn{3}{|c|}{$0.1 \$ / h$} & \multicolumn{2}{|c|}{$30 \%$} & \multicolumn{2}{|c|}{$1000 \$ / k W$} & \multicolumn{3}{|c|}{20 years } & \multicolumn{2}{|c|}{$95 \%$} \\
\hline \multicolumn{8}{|c|}{ Fuel cell } & \multicolumn{6}{|c|}{ Electrolyzer } \\
\hline \multicolumn{2}{|c|}{ Price } & \multicolumn{2}{|c|}{ Lifetime } & $\begin{array}{r}\text { Mainte } \\
\text { co }\end{array}$ & $\begin{array}{l}\text { nance } \\
\text { st }\end{array}$ & $\begin{array}{l}\text { Minin } \\
\text { load } r\end{array}$ & um & & ice & & Lifetime & Effi & ciency \\
\hline $2000 / 4000$ & $6000 \$ / \mathrm{kW}$ & 150 & $0 \mathrm{~h}$ & 0.05 & $\$ / h$ & $6 \%$ & & $1500 / 5$ & $000 \$ / \mathrm{kW}$ & & LO years & & $30 \%$ \\
\hline & Hyd & ggen $t$ & ank & & & & & & & & & & \\
\hline & & & Price & & Lifetime & & & & & & & & \\
\hline Compress & (200 bar) & 600 & $\$ / \mathrm{kg}\left(\mathrm{H}_{2}\right)$ & & 20 years & & & & & & & & \\
\hline
\end{tabular}




\section{References:}

[1] http://www.energy.eu/ (last viewed on November 2011).

[2] http://www.hep.hr/ods/en/customers/Tariff.aspx (last viewed on November 2011).

[3] Kaldellis JK. Optimum hybrid photovoltaic-based solution for remote telecommunication stations. Renew Energy 2010; 35:2307-15.

[4] Schultz MT, Diehl T, Brasseur GP, Zittel W. Air Pollution and Climate- Forcing Impacts of a Global Hydrogen Economy. Science 2003; 302:624-7.

[5] http://www1.eere.energy.gov/hydrogenandfuelcells/production/natural_ga s.html (last viewed on November 2011).

[6] Harrison KW. Design, Integration and Control of Proton Exchange Membrane Electrolyser for Wind Based Renewable Energy. PhD dissertation 2006. Universitiy of North Dakota.

[7] http://intuitech.biz/?p=7687 (last viewed on November 2011).

[8] Zhang J, et al. High temperature PEM fuel cells. J Power Sources 2006; 160:87291.

[9] Zoulias EI, Lymberopoulos N. Techno-economic analysis of the integration of hydrogen energy technologies in renewable energy-based stand-alone power systems. Renew Energy 2006; 32:680-96.

[10] http://www.fuelcells.org/info/charts/h2fuelingstations.pdf (last viewed on November 2011).

[11] http://www.altfuelprices.com/ (last viewed on November 2011).

[12] Chandler K, Eudy L. Connecticut Transit (CTTRANSIT) Fuel Cell Transit Bus: Third Evaluation Report 2010. Technical Report NREL/TP-560-47334-1.

[13] Saur G. Wind-To-Hydrogen Project: Electrolyzer Capital Cost Study. Technical Report NREL/TP-550-44103 December 2008.

[14] Liu BYH, Jordan RC. Daily insolation on surfaces tilted towards the equator. Trans ASHRAE 1962; 67:526-41.

[15] Klein SA. Calculation of monthly average insolation on tilted surfaces. Sol Energy 1977; 19:325-9.

[16] HOMER, The optimization model for distributed power, 1993. National Renewable Energy Laboratory. https://analysis.nrel.gov/homer/ (last viewed on November 2011).

[17] Brankera K, Pathaka MJM, Pearce JM. A review of solar photovoltaic levelized cost of electricity. Renewable and Sustainable Energy Reviews 2011; 15: 447082.

[18] http://www.solarbuzz.com/node/3184 (last viewed on November 2011).

[19] Bergey M. Village electrification: hybrid systems. Wind Energy applications and training symposium 2000. 